\title{
Changes in photoperiod and nutrition and their effect on testicular growth of rams
}

\author{
D. R. Lindsay*, J. Pelletier, C. Pisselet and M. Courot \\ Laboratoire de Physiologie de la Reproduction, INRA, 37380 Nouzilly, France
}

\begin{abstract}
Summary. Groups of 6 Ile-de-France rams were housed in light-proof rooms and subjected in a factorial design to two light regimens, $180^{\circ}$ out of phase, and two levels of protein in their diets. The daily duration of daylight was varied sinusoidally to produce 6-month years with 'winters' of $8 \mathrm{~h}$ light and 'summers' of $16 \mathrm{~h}$ light. The diets were formulated to supply $50 \%$ above or $25 \%$ below maintenance requirements in protein. Testicular diameter and volume increased with decreasing light and decreased with increasing light but the diet had no effect. The frequency of LH pulses was measured monthly and was high ( $3 / 12 \mathrm{~h}$ per ram) when the daylight was being reduced and low $(1 / 12 \mathrm{~h}$ per ram) when it was increased. At the extremes of the duration of dark or light the frequency of pulses was around $1.6 / 12 \mathrm{~h}$ per ram, regardless of the duration of light. The two diets had no effect on testicular dimensions but rams fed the 'high' protein diet had a total of $175 \mathrm{LH}$ pulses, which was significantly higher $(P<0.05)$ than the 131 pulses recorded from rams on the 'low' protein diet.

It is concluded that, in these '6-month years', decreasing light stimulates LH pulsatility and testicular growth and increasing light is inhibitory. Pulsatility of LH appears to be influenced by the protein level in the diet.
\end{abstract}

\section{Introduction}

Changes in daylength with season are the signal which controls the seasonal changes in testicular size and reproductive activity of some breeds of ram (Ortavant, Mauléon \& Thibault, 1964). Rams have heavier testes in the autumn than in spring and this relationship holds even when the animals are subjected artificially to 6-month 'annual' cycles (Ortavant \& Thibault, 1956). Lincoln, Peet \& Cunningham (1977) showed that the frequency of episodic release of LH was high when rams were given $8 \mathrm{~h}$ light per day and low when they were given $16 \mathrm{~h}$ light and that daylength, by modifying gonadotrophin secretion, is probably the principal factor regulating testicular growth. This was substantiated further (Lincoln, 1979) when rams were given artificial pulses of LHRH in the spring; this caused regressed testes to grow to a size normally seen in the breeding season during autumn. Most experiments on the effect of daylength on frequency of LH pulses in peripheral blood have compared treatments in which the daylength remained constant or was changed, literally overnight, from one extreme to another. Under natural conditions daylength varies sinusoidally throughout the year and the rate of change varies from a maximum at the equinoxes to a minimum at the solstices. This means that when animals are experiencing the greatest contrast between day and night they are also experiencing the least change in the light:dark ratio.

In the Australian Merino, testicular size has been shown to be controlled by nutrition (Oldham, Adams, Gherardi, Lindsay \& Mackintosh, 1978) even to the extent that well-fed rams in spring

* Present address: School of Agriculture (Animal Science), University of Western Australia, Nedlands, Western Australia 6009, Australia.

(C) 1984 Journals of Reproduction \& Fertility Ltd 
may have larger testes than poorly-fed rams in autumn (Masters \& Fels, 1984). As with photoperiod, nutrition appears to mediate its effect through changing the frequency of pulses of LH (Sutherland \& Martin, 1980).

For animals grazing outdoors the interaction between daylength and nutrition is potentially important. The experiment in this paper sought to determine the relative influences of changes in daylength and differences in nutrition on testicular size and $\mathrm{LH}$ production of rams. The hypotheses we tested were (1) that $\mathrm{LH}$ pulses are quantitatively related to rate of change in daylength and (2) that nutrition can modify the response to this rate of change.

\section{Materials and Methods}

\section{Experimental design}

The experiment had a factorial design with two light regimens (1 and 2) and two nutritional regimens ( $\mathrm{H}$ and $\mathrm{L}$ ). Ile-de-France rams, all born in February to April 1979, were allocated at random into 4 groups $(1 \mathrm{H}, 1 \mathrm{~L}, 2 \mathrm{H}$ and $2 \mathrm{~L})$ each of 6 rams. The animals were placed in 2 lightproofed rooms on 23 December 1980 and underwent '6-month years'. The light regimen was varied to conform to a sine curve by manually adjusting automatic time switches in 15 -min steps at appropriate intervals. Daylength varied from a minimum of $8 \mathrm{~h}$ to a maximum of $16 \mathrm{~h}$. Animals in the first room, Groups $1 \mathrm{H}$ and $1 \mathrm{~L}$, began the experiment at the same daylength as they were experiencing outdoors, but those in the second room, Groups $2 \mathrm{H}$ and $2 \mathrm{~L}$, passed directly from $8 \mathrm{~h}$ natural light to $16 \mathrm{~h}$ of artificial light and began a sinusoidal light rhythm, the inverse of that in the other room. Each day all the rams ate $1200 \mathrm{~g}$ of a maintenance ration of straw ( $42 \%$ ), soyabean meal $(4 \%)$, oat grain $(8 \%)$, and maize (46\%) from 23 December 1980 until 27 March 1981. The ration provided $66 \mathrm{~g}$ digestible crude protein and 7.2 MJ digestible energy (Tissier \& Theriez, 1978). From 28 March Groups $1 \mathrm{~A}$ and $2 \mathrm{~A}$ received a ration calculated to give a level of protein $25 \%$ less than maintenance. The diets were calculated to have the same level of energy.

\section{Sampling procedures}

Starting in December rams were weighed every month after overnight fasting. As an indicator of effective protein supply to the sheep (Reis \& Schinckel, 1964) the daily growth rate of wool was calculated at approximately 3-week intervals after the two dietary treatments began. A sample of wool was shorn from $100 \mathrm{~cm}^{2}$ on the middle right side of each animal with a fine-tooth animal clipper. This sample was weighed after washing in $1 \%$ Teepol and rinsing in water ( 3 times), alcohol, and petroleum ether, and then drying overnight in an oven at $40^{\circ} \mathrm{C}$ to constant weight. Daily growth rate of wool was calculated by dividing the weight by the number of days since the last sample was taken.

Every 2 weeks from 6 January until 15 September the diameters of the testes were measured using calipers. Starting on 3 February the volumes of the testes were also measured every 2 weeks using an orchidometer. Each of these measurements was made by the same person throughout the experiment to minimize between-operator variation. Sampling of blood began on 25 March 1981 . Each month 13 samples of $5 \mathrm{ml}$ blood were taken from each ram at hourly intervals. Sampling began $2 \mathrm{~h}$ after the artificial 'dawn' because previous work had shown that this should include the period of most frequent discharge of hormone pulses during the day (Ortavant et al., 1982). During the dark, blood was collected under a very weak, green light. Plasma was separated and deep frozen until assayed.

The LH was assayed and the peaks determined using duplicate samples by the method of Pelletier, Kann, Dolais \& Rosselin (1968) with modifications described by Pelletier, Garnier, de Reviers, Terqui \& Ortavant (1982). Characteristics of the assay were: (1) the percentage transfer of ${ }^{125}$ I to LH during iodination was $90 \%$ resulting in a specific activity of $100.8 \mathrm{Ci} / \mathrm{pg} \mathrm{LH}$; (2) all of 
the samples were assayed simultaneously in an automatic LKB 2071 sample processor; (3) results were expressed in terms of LH-M3 $(=1.8 \times \mathrm{NIH}-\mathrm{LH}-\mathrm{SI}) ;(4)$ the sensitivity was $0.09 \mathrm{mg} / \mathrm{ml}$ plasma; and (5) the within-assay coefficient of variation was $4 \%$. A peak was defined as an increase in hormonal concentration to a value greater than 4 times the coefficient of variation of the baseline, followed by a decrease. Data from Terqui, Garnier, de Reviers, Huet \& Pelletier (1980) and Pelletier et al. (1982) indicate that a sampling interval of $1 \mathrm{~h}$ allows detection of $93-95 \%$ of all $\mathrm{LH}$ peaks in entire rams.

Because of the discontinuity in data for pulses, appropriate non-parametric tests were used for statistical analyses.

\section{Results}

The live weight of the animals rose only slightly throughout the experiment and did not differ significantly between dietary treatments (Text-fig. 1). By contrast, regression analysis showed that the daily rate of growth of wool fell significantly in those animals receiving the lower level of protein but did not differ significantly over the 6 months of feeding in those animals receiving the higher protein diet.

The testes responded strongly to changes in daylength. The estimated volume varied from about $125 \mathrm{ml} /$ testis at the end of the period of long daylength to about $250 \mathrm{ml}$ at the end of the period of short days (Text-fig. 2). The diameters of the testes varied in parallel. The nutritional regimens had no significant influence on the effects induced by changes in daylength.

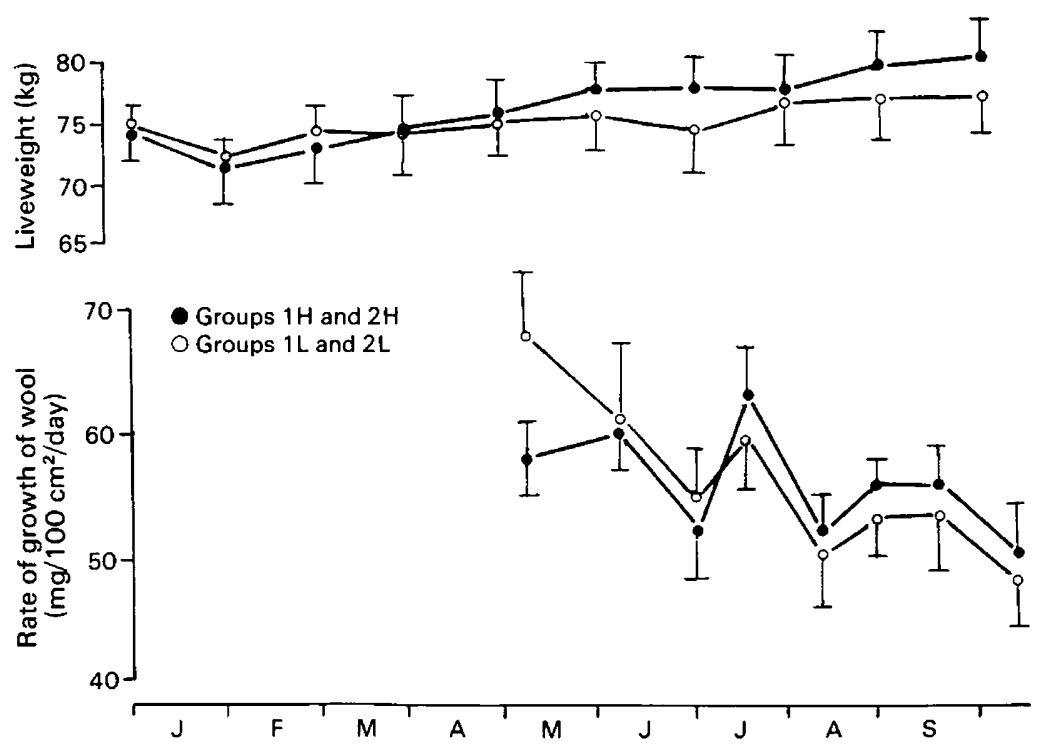

Text-fig. 1. Liveweight and wool production of rams throughout the experiment. Values are mean \pm s.e.m. for 6 rams/group.

The frequency of pulsatile discharge of LH, expressed as the number of peaks per 6 rams per $12 \mathrm{~h}$, is superimposed on a diagram of the light regimen and is shown in Text-fig. 3. Frequency of pulses was high during the phase of decreasing daylength $(2.9 \mathrm{pulses} / 12 \mathrm{~h}$ per ram $)$. The influence of light treatments was significant for each of the 4 groups of 6 rams $(P<0.01$; Kruskal-Wallis test $)$. Samples taken when the animals were subjected to daylight of $13 \mathrm{~h} 20 \mathrm{~min}$ or $10 \mathrm{~h} 40 \mathrm{~min}$ had significantly more LH pulses when the daylength was falling than when it was increasing (pooled samples for all groups: $P<0.001 ;$ Mann-Whitney test). The only individual exception to this was 


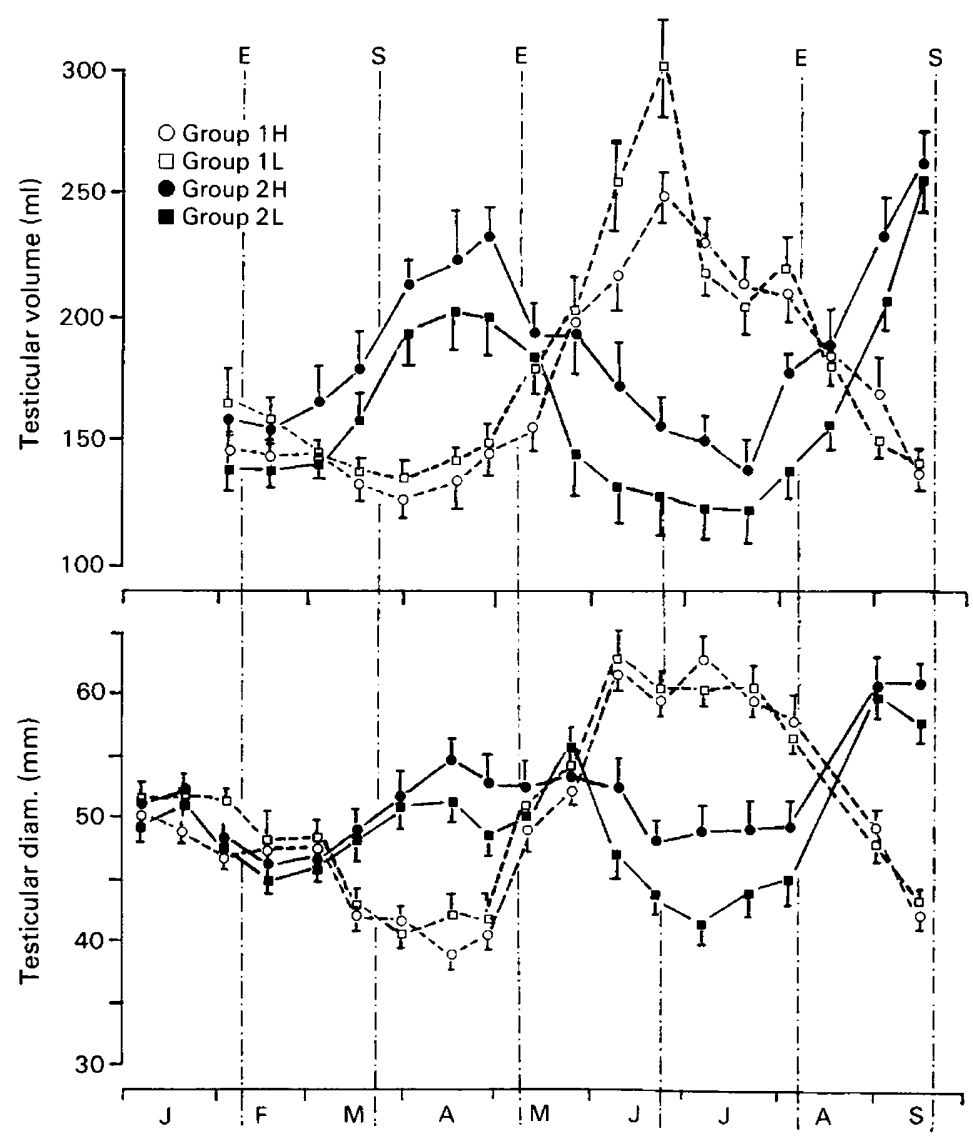

Text-fig. 2. Variation in estimated volumes and diameters of testes of rams subjected to changing daylength $(E=$ equinox $; S=$ solstice $)$. Values are means \pm s.e.m. for 6 animals, one testis per animal.

once in Group 2, probably because these animals began the experiment by changing completely in one day from 8 to $16 \mathrm{~h}$ of light and had not settled down until the second cycle. During this second cycle the highest number of $\mathrm{LH}$ pulses per $12 \mathrm{~h}$ was recorded with $10 \mathrm{~h} 40$ min daylight during the reducing phase and the lowest number was recorded with $13 \mathrm{~h} 20 \mathrm{~min}$ daylight in the increasing phase. There was an 8 -fold difference between the two recordings. In almost all animals the frequency of pulses at $16 \mathrm{~h}$ was greater than that 1 month earlier when there was only $13 \mathrm{~h} 20 \mathrm{~min}$ of light. Similarly, during the shortest days pulses were less frequent than when the animals had received $10 \mathrm{~h} 40 \mathrm{~min}$ of daylight 1 month before.

The total number of pulses at $8 \mathrm{~h}$ of daylight (55) was not significantly different from that at $16 \mathrm{~h}$ (60) so that at the solstices rams had about 1.6 pulses per $12 \mathrm{~h}$ regardless of the duration of light. In Groups $1 \mathrm{H}$ and $1 \mathrm{~L}$ the delay between the maximum pulsatility of $\mathrm{LH}$ and the maximum testicular volume was about 1 month.

There was a significant effect of nutrition on the total number of peaks of LH. Rams on the 'high' protein diet had a total of 175 pulses and those on the 'low' protein diet had only 131 pulses $(P<0.05 ;$ Mann-Whitney test). This difference in frequency of peaks of LH was not reflected in a difference in testicular size. There was no interaction between the nutritional status and the light regimens for pulses of $\mathbf{L H}$.

The distribution of frequencies of pulses found in the 13 sequential samples starting from $2 \mathrm{~h}$ after 'dawn' was homogeneous ( $P \bumpeq 0 \cdot 1$; Cochran's $q$ test $)$. 


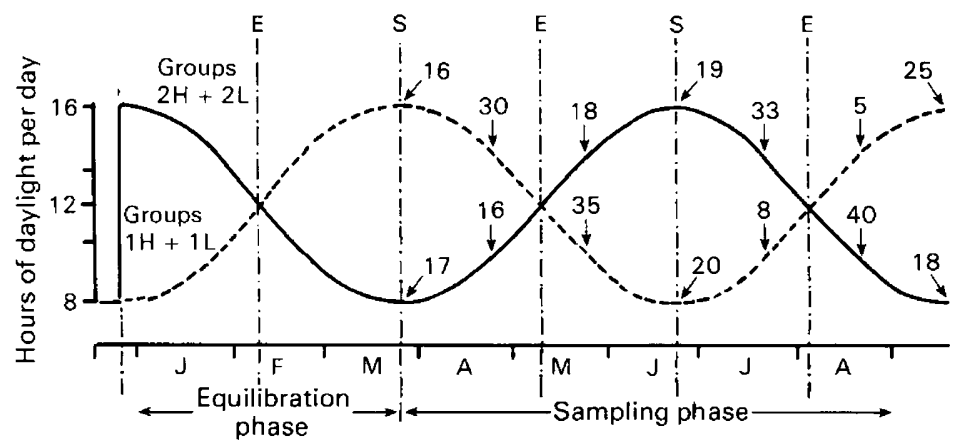

Text-fig. 3. Light regimens for the rams in the present study. The numerical values give the no. of LH pulses/ 6 rams per $12 \mathrm{~h}$ when sampling was carried out every month. $\mathrm{E}=$ equinox; $\mathrm{S}=$ solstice.

\section{Discussion}

This experiment demonstrates that the growth and regression of testes in rams are highly dependent on the photoperiod. It has been shown by a number of workers that a change from long to short days stimulates testicular development (Marshall, 1937; Ortavant et al., 1964; Lincoln et al., 1977). In this experiment we have extended this by showing that one of the endocrine stimuli to testicular growth, pulses of LH (Lincoln, 1977), is sensitive to the rate of change of daylight. The difference between the lengths of light and dark is most pronounced at the solstices. Despite this, pulses were less frequent at the 'winter' solstice and more frequent at the 'summer' solstice, and more frequent than they were 1 month earlier when the rate of change of daylength was more rapid. In fact, when approached through a sinusoidal curve of photoperiodic change the LH pulse frequency at $16 \mathrm{~h}$ of light was no different from that at $8 \mathrm{~h}$ of light. The ram therefore seems able to anticipate a change in direction of the light : dark ratio before it occurs. In this experiment and that of Pelletier et al. (1982) it has been shown that the hypothalamo-hypophysial system can be stimulated during long days and can be inhibited during short days, which is further evidence that rate of change of daylength is at least as potent a force as the absolute lengths of the light and dark phases in controlling seasonal endocrine activity. This is possibly why testicular diameter and volume begin to increase or regress soon after the longest or shortest day when the changes might be expected to be later than this before the differences become measurable.

Ortavant et al. (1982), using a '12-month-year' found a clear probability of larger numbers of LH pulses 3-4 h after 'dawn' than at other times, and Lincoln (1977) found that frequency of LH pulses was related to activity. In our experiment using a ' 6 -month year' there was no significant variation in the number of peaks of LH throughout the $12 \mathrm{~h}$ beginning $2 \mathrm{~h}$ after dawn.

The feed regimens imposed significantly affected the number of LH pulses per unit time but had little effect on testicular diameter or volume, certainly less than one might have expected from the results of Oldham et al. (1978). There was a significant but small drop in the growth rate of wool in the group fed a low protein diet but comparisons of the growth rates of wool between the animals receiving high and low protein diets suggest that the differences in the effective supply of protein to the animals were not as great as could be expected from the ingredients. Therefore, differences in diet that are not clearly measurable by differences in live weight may have endocrine effects. The fact that these endocrine differences were not matched by corresponding differences in testicular size suggests that the well-known relationship between testicular growth and frequency of pulses of LH may be more of an 'all or none' than a simple linear response.

We thank Mr C. Cornu and his staff for preparing the animals and looking after them during the experiment. D.R.L. received a French Government scholarship during his period of study leave at Nouzilly. 


\section{References}

Lincoln, G.A. (1977) Changes in pituitary responsiveness to luteinizing hormone releasing hormone in rams exposed to artificial photoperiods. J. Endocr. 73, 519527.

Lincoln, G.A. (1979) Use of a pulsed infusion of luteinizing hormone releasing hormones to mimic seasonally induced endocrine changes in the ram. $J$. Endocr. 83, 251-260.

Lincoln, G.A., Peet, M.J. \& Cunningham, R.A. (1977) Seasonal and circadian changes in the episodic release of follicle-stimulating hormone, luteinizing hormone and testosterone in rams exposed to artificial photoperiod. J. Endocr. 72, 337-349.

Marshall, F.H.A. (1937) On the change over in the oestrous cycle in animals after transference across the equator, with further observations on the incidence of the breeding seasons and the factor controlling sexual periodicity. Proc. $R$. Soc. B 122, 413-428.

Masters, D.G. \& Fels, H.E. (1984) Seasonal changes in the testicular size of grazing rams. Proc. Aust. Soc. Anim. Prod. 15, 444-447.

Oldham, C.M., Adams, N.R., Gherardi, P.B., Lindsay, D.R. \& Mackintosh, J.B. (1978) The influence of level of feed intake on sperm-producing capacity of testicular tissue in the ram. Aust. J. agric. Res. 29, 173-179.

Ortavant, R. \& Thibault, C. (1956) Influence de la durée d'éclairement sur les productions spermatiques du Bélier. C. r. Séanc. Soc. Biol. 2, 358-361.

Ortavant, R., Mauléon, P. \& Thibault, C. (1964) Photoperiodic control of gonadal and hypophyseal activity in domestic animals. Ann. N.Y. Acad. Sci. 117, 157-193.

Ortavant, R., Daveau, A., Garnier, D.H., Pelletier, J., de Reviers, M.M. \& Terqui, M. (1982) Diurnal variation in release of $\mathrm{LH}$ and testosterone in the ram. $J$. Reprod. Fert. 64, 347-353.

Pelletier, J., Kann, G., Dolais, J. \& Rosselin, G. (1968) Dosage radioimmunologique de l'hormone luteinisante plasmatique de mouton. Mise au point de la technique de dosage. C. r. hebd. Séanc. Acad. Sci., Paris, D 266, 2291-2294.

Pelletier, J., Garnier, D.H., de Reviers, M.M., Terqui, M. \& Ortavant, R. (1982) Seasonal variation in $\mathrm{LH}$ and testosterone release in rams of two breeds. J. Reprod. Fert. 64, 341-346.

Reis, P.J. \& Schinckel, P.G. (1964) The growth and composition of wool. II. The effect of casein, gelatin and sulphur-containing amino acids given per abomasum. Aust. J. biol. Sci. 17, 532-547.

Sutherland, S.R.D. \& Martin, G.B. (1980) The effect of a supplement of lupin seed on the testicular size and LH profiles of Merino and Booroola rams. Proc. Aust. Soc. Anim. Prod. 13, 459, Abstr.

Terqui, M., Garnier, D.H., de Reviers, M.M., Huet, S. \& Pelletier, J. (1980) La structure chronologique du dialogue entre l'hypophyse et les gonades chez les mammifères domestiques. In Rythmes et Reproduction, pp. 59-72. Eds R. Ortavant \& A. Reinberg. Masson, Paris.

Tissier, M. \& Theriez, M. (1978) Alimentation des Ruminants, pp. 403-448. INRA, Paris.

Received 8 July 1983 